\title{
Thermo-tectonic History of the Marlborough Region, South Island, New Zealand
}

\author{
Ming-Hung $\mathrm{Kao}^{1, *}$ \\ (Manuscript received 4 January 2001, in final form 18 July 2001)
}

\begin{abstract}
Apatite fission track analysis has been used to study the thermal and tectonic history of the Marlborough Region, South Island, New Zealand. The very young ages ( $<10 \mathrm{Ma}$ ) of apatite in the vicinity of the Alpine Fault bend and Seaward Kaikoura Range, are consistent with the recent rapid uplift/erosion in these areas. Most of the apatite ages are younger than depositional ages, indicating that the host rocks in Marlborough have experienced exposure to temperatures in the zone of partial annealing for apatite. In addition, apatite ages obtained along the Wairau Fault are always younger than those of other areas. Apatite fission track ages and mean lengths show that there are two major cooling events, one occurring from the early Miocene ( $20 \mathrm{Ma})$ and the other in the mid-Cretaceous ( 100 Ma). Modeled thermal histories of eleven samples selected from Marlborough samples are consistent with the stratigraphic record and reflect that in the Wairau block the timing of the main Neogene uplift/erosion event is earlier (mid to late Miocene) than to the southeast in the Seaward Kaikoura Range (late Pliocene-Pleistocene).
\end{abstract}

(Key words: Apatite fission track analysis, Annealing, Closure temperature)

\section{INTRODUCTION}

Apatite fission track thermochronology is a powerful method for establishing low-temperature thermal histories of rock successions (Naeser 1979; Laslett et al. 1987; Green et al. 1989a, 1989b; Kamp et al. 1989; Kamp and Tippett 1993; Rohrman et al. 1994; Kao 1998).

Apatite fission track data provide not only information about numerical ages but also estimation of the thermal history of host rocks. Fission tracks in U-bearing crystals such as apatite result from the spontaneous fission of ${ }^{238} \mathrm{U}$, and can be applied to thermal and tectonic studies. The annealing of fission tracks is an important aspect of the fission track

${ }^{1}$ Institute of Earth Sciences, Academia Sinica, Taipei, Taiwan, ROC

* Corresponding author address: Dr. Ming-Hung Kao, Institute of Earth Sciences, Academia Sinica, P.O. Box 1-55, Nankang, Taipei, Taiwan, ROC; E-mail: mhkao@ earth.sinica.edu.tw 
thermochronometer. Because of a kinetic understanding of annealing in apatite (Green et al. 1986, 1989b; Laslett et al. 1987; Duddy et al. 1988; Crowley et al. 1991), thermal histories can be reconstructed from forward modeling of time-temperature histories and comparison of predicted and measured fission track ages and lengths. Different minerals have different "closure temperatures". "Closure temperature " is a concept that links the observed age to the temperature at which fission track age starts to accumulate (Dodson 1973; Hodges 1991). For example, the closure temperature for apatite ranges from $110^{\circ} \mathrm{C}$ to $125^{\circ} \mathrm{C}$ depending on apatite composition (Gleadow and Duddy 1981; Green et al. 1989b).

In this study, apatite fission track analysis is applied to assess the thermal and tectonic history of basement in Marlborough. The results of apatite fission track data will be discussed in four sub-regions: the Wairau, Inland Kaikoura, Seaward Kaikoura, and Kahutara. Additionally, the software of fission track thermal history modeling (Monte Trax), developed by Gallagher (1995), is used to reconstruct the thermal histories of selected samples with good track length data.

\section{GEOLOGIC AND TECTONIC SETTINGS}

\subsection{Geologic Setting}

The Torlesse Supergroup constitutes the basement of the Marlborough region. Bradshaw et al. (1981) explained that the angular unconformity separating the Torlesse Supergroup from younger units, represents the stratigraphic expressions of the end of the early Cretaceous Rangitata Orogeny. The age of basement rocks ranges from the Late Jurassic to Early Cretaceous, with Triassic successions in the far west. The Alpine Schist crops out adjacent to the Alpine Fault. Its exposure is a result partly of Cretaceous denudation (Suggate 1978) but mainly Neogene denudation, as is shown here. The depositional ages of cover strata range from Cretaceous to Quaternary (Fig. 1). Early Cenozoic sequences accumulated during a tectonically quiet period when Marlborough was part of a passive margin environment. This was followed by the Kaikoura Orogeny, dating from the early Miocene, which reflects development of the modern Australia-Pacific plate boundary in the region (Browne 1995). In Marlborough, magmatism and extension occurred at about $100 \mathrm{Ma}$. After the initiation of extension and magmatism ( $100 \mathrm{Ma})$, marine sedimentary sequences (greensands/limestone) accumulated and subsided through thermally controlled processes (Lensen 1962). This tectonic quiescence lasted from 90 to $25 \mathrm{Ma}$ (Baker and Seward 1996). From the early Miocene onwards, crustal shortening and strike-slip faulting are considered to have become increasingly important in the Marlborough region (Carter and Norris 1976; Suggate 1978; Baker and Seward 1996).

\subsection{Tectonic Setting}

The Marlborough region lies within the Australian-Pacific plate boundary zone (Fig. 1) at a critical position between the southem end of the Hikurangi margin (where the oceanic Pacific plate subducts beneath the continental Australia plate) and the Alpine Fault section (where the continental Pacific plate collides with continental Australia plate). The Marlborough faults 


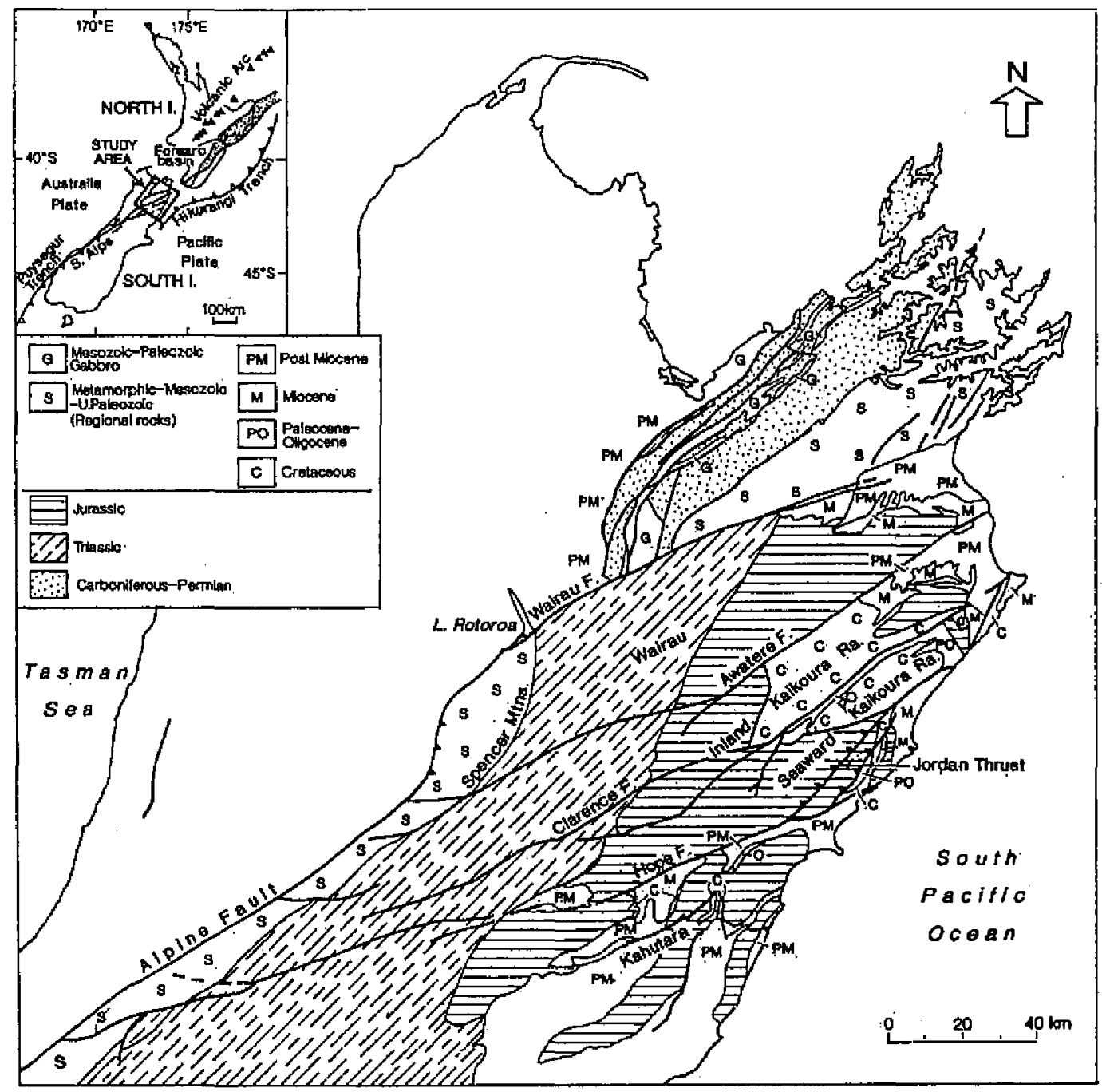

Fig. 1. Tectonic and geological map of the Marlborough region, South Island, New Zealand.

have usually been explained as secondary transforms connecting the Hikurangi subduction margin with the main Alpine Fault oblique-slip boundary (Wellman 1971; Christoffel 1971). Stock and Molnar (1982) stated that a change in the direction of migration of the AustralianPacific pole of rotation occurred about $9.8 \mathrm{Ma}$ ago. The subduction of the Pacific plate has probably propagated southwards during the Late Neogene, causing continuous activation of the Marlborough Faults (Carter and Carter 1982). Several palaeomagnetic studies while documenting the occurrence of rotations of blocks between the faults also support this concept of successive propagation of faults during the Neogene (Walcott 1978; Lamb 1988; Mumme et al. 1989; Roberts 1992; Vickery and Lamb 1995). 


\section{SAMPLING AND EXPERIMENTAL PROCEDURES}

\subsection{Sampling}

Eighty-eight samples (9414-1 to -88) were collected from outcrops along roads throughout Marlborough, or by helicopter from the Seaward Kaikoura Range. Most of the samples were taken from within the Marlborough Fault System and the region of the Alpine Fault bend. These samples can be divided into four groups, located at four sub-regions respectively (Fig. 1). The four sub-regions are: the Wairau, Inland Kaikoura, Seaward Kaikoura, and Kahutara.

\subsection{Experimental Procedures}

The experiment procedures applied in this study were followed using the methods described in the papers of Green (1986), Kamp et al. (1989), and Tippett and Kamp (1993). Apatite concentrates separated from rock samples ( 3 to $4 \mathrm{~kg}$ ) were obtained by various methods, including standard magnetic and heavy liquid techniques. The apatite concentrates were mounted in Petropoxy ${ }^{\mathrm{TM}}$ resin at $\sim 140^{\circ} \mathrm{C}$ on glass slides and ground with silicon carbide paper to disclose internal crystal surfaces. After polishing with a slurry of alumina powder, the crystals were then etched in $5 \mathrm{M} \mathrm{HNO}_{3}$ for 20 s at $\sim 24^{\circ} \mathrm{C}$.

The following procedures were followed: (a) all mounts were cut to $1 \times 1.5 \mathrm{~cm}$ and cleaned with detergent and alcohol, (b) low-uranium mica external detectors were sealed directly in contact with the mounts by using envelopes of heat-shrink plastic, (c) pinpricks were made at the corners of each mount-mica sandwich for subsequent location, (d) all mounts were stacked vertically with dosimeter glass standards (SRM 612 for apatites) placed at the top and bottom of each stack for irradiation. Each dosimeter was also mounted with a mica detector. Afterwards, all stacks were packed into canisters and irradiated in the X-7 facility of the HIFAR reactor, New South Wales, Australia. The nominal fluences of thermal neutrons were $1 \times 10^{16}$ to $5 \mathrm{x}$ $10^{16}$ neutrons $\mathrm{cm}^{-2}$ for apatites.

In this study, the external detector method described by Gleadow (1981) was applied in the dating. The fission track ages were determined by using the zeta calibration method (Hurford and Green 1982; Green 1985). The measurement of fission track lengths was followed by using the recommendations of Laslett et al. (1982). A chi-square statistic was used to determine the probability of grains counted in a sample belonging to a single population of ages (Galbraith 1981). The results of weighted mean zetas are reported in Table 1. The apatite weighted mean $\zeta$ is $348.4 \pm 5.8$ (SRM 612). The results of calibration of horizontally confined track length determinations on apatite are listed in Table 2.

\section{FISSION TRACK RESULTS AND MODELED THERMAL HISTORY}

Apatite fission track results reveal that the fission track data are strongly influenced by the regional tectonics. The fission track data for Marlborough samples are shown in Table 3. The distributions of apatite fission track ages and track lengths are shown in Figs. 2 and 3. Uncer- 
Table 1. Results of calibration of fission track age determinations by the zeta approach.

\begin{tabular}{|c|c|c|c|c|c|c|c|c|c|c|}
\hline \multirow{2}{*}{$\begin{array}{l}\text { Age Standarc and } \\
\text { Irradiation No. }\end{array}$} & \multirow{2}{*}{$\begin{array}{c}\text { Mineral } \\
\text { (No. of crystals) }\end{array}$} & \multicolumn{2}{|c|}{ Spontaneous } & \multicolumn{2}{|c|}{$\underline{\text { Induced }}$} & \multirow{2}{*}{$\begin{array}{r}P\left(\chi^{2}\right) \\
\%\end{array}$} & \multirow[t]{2}{*}{ Glass } & \multicolumn{2}{|r|}{ Dosimeter } & \multirow[t]{2}{*}{$\zeta \pm 1 \sigma$} \\
\hline & & $\rho s$ & $\mathrm{~N}_{\mathrm{s}}$ & & $\rho_{i} \quad \mathrm{~N}$ & & & & $\rho \quad N_{d}$ & \\
\hline Durango wk043 & Apatite (20) & 0.182 & 536 & 0.866 & 2548 & 90.6 & SRM 612 & 0.9260 & 4581 & $323.2 \pm 16.9$ \\
\hline Durango wk044 & Apatite (20) & 0.186 & 496 & 0.915 & 2433 & 100 & SRM 612 & 0.9151 & 4525 & $337.4 \pm 18.2$ \\
\hline Fish Canyon pt836 & Apatite (20) & 0.181 & 339 & 1.309 & 2452 & 100 & SRM 612 & 1.1260 & 5570 & $359.2 \pm 23.2$ \\
\hline Fish Canyon pt836 & Apatite (20) & 0.224 & 209 & 1.456 & 1359 & 99.1 & SRM 612 & 1.1260 & 5570 & $322.9 \pm 25.7$ \\
\hline Fish Canyon pt836 & Apatite (20) & 0.213 & 199 & 1.374 & 1281 & 99.0 & SRM 612 & 1.1260 & 5570 & $319.7 \pm 26.0$ \\
\hline Fish Canyon wk043 & Apatite (20) & 0.186 & 237 & 1.129 & 1440 & 98.2 & SRM 612 & 0.9151 & 4525 & $371.3 \pm 28.2$ \\
\hline Fish Canyon wk044 & Apatite (20) & 0.203 & 326 & 1.218 & 1953 & 73.2 & SRM 612 & 0.9260 & 4581 & $361.8 \pm 24.1$ \\
\hline Mt Dromedary pt836 & Apatite (20) & 0.765 & 1040 & 1.552 & 2111 & 96.3 & SRM 612 & 1.1260 & 5570 & $358.6 \pm 14.6$ \\
\hline Mt Dromedary pt836 & Apatite (20) & 0.786 & 1555 & 1.564 & 3094 & 100 & SRM 612 & 1.1260 & 5570 & $351.5 \pm 12.1$ \\
\hline Mt Dromedary pt836 & Apatite (20) & 0.996 & 1902 & 1.996 & 3809 & 99.9 & SRM 612 & 1.1260 & 5570 & $357.3 \pm 7.6$ \\
\hline Mt Dromedary pt836 & Apatite (20) & 0.931 & 1366 & 1.897 & 2784 & 98.5 & SRM 612 & 1.1260 & 5570 & $360.0 \pm 13.0$ \\
\hline Mt Dromedary wk043 & Apatite (20) & 0.957 & 1528 & 1.465 & 2338 & 46.6 & SRM 612 & 0.9151 & 4525 & $332.6 \pm 12.2$ \\
\hline Mt Dromedary wk044 & Apatite (20) & 0.624 & 995 & 1.112 & 1772 & 64.6 & SRM 612 & 0.9260 & 4581 & $382.6 \pm 16.3$ \\
\hline & & & & & & & & Apa & tite Mean $\zeta$ & $348.4 \pm 5.8$ \\
\hline
\end{tabular}

Analyses of apatite age standards are by external detector method; track densities $(\rho)$ are $\left(\times 10^{6} \mathrm{~cm}^{-2}\right) ; \mathrm{N}$ is number of racks counted. $\mathrm{P}\left(\chi^{2}\right)$ is the probability of obtaining $\chi^{2}$ value for $v$ degrees of freedom where $v=\left(\right.$ Number of crystals-1) [Galbraith 1981]; pooled $\rho_{\xi} / \rho_{1}$, ratio used to calculate $\zeta$ and uncertainty where $\mathrm{P}\left(\chi^{2}\right)>5 \%$; mean $\rho_{\delta} \rho_{\mathrm{i}}$ ratio used to calculate $\zeta$ and uncertainty where $\mathrm{P}\left(\chi^{2}\right)>5 \%$ [Green 1981]. Standard ages used are Fish Canyon Tuff 27.8 $\pm 0.7 \mathrm{Ma}$, Tardree Rhyolite $58.7 \pm 1.1 \mathrm{Ma}$ [Hurford and Green. 1983]; Durango apatite $31.4 \pm 0.5$, Mount Dromedary Igneous Complex 98.7 $\pm 0.6 \mathrm{Ma}$, Lake Mountain Rhyodacite 367.6 $\pm 1.5 \mathrm{Ma}$, Mount Warning Complex 22.8 \pm 0.5 Ma [Green 1985]; Buluk Member tuff $16.2 \pm 0.2 \mathrm{Ma}$ [Hurford and Watkins 1987]. An uncertainty component from the independent age is included in the error on each $\zeta$ value; apatite mean $\zeta$ and its error weighted according to uncertainties on individual $\zeta$ values. Apatite $\zeta$ determination fulfils the requirements proposed by Hurford[1990]. 
Table 2. Results of calibration of horizontally confined track length determinations on apatite.

\begin{tabular}{llccc} 
Standard & Sample & Number of Tracks & Mean length $\pm 1 \sigma, \mu \mathrm{m}$ & Standard Deviation $\sigma, \mu \mathrm{m}$ \\
\hline Durango & $8794-1$ & 44 & $14.10 \pm 0.10$ & 0.69 \\
Durango & Sample mean & & $14.10 \pm 0.10$ & \\
& & 27 & $15.20 \pm 0.20$ & 1.01 \\
Fish Canyon & $8794-5$ & 52 & $14.86 \pm 0.11$ & 0.77 \\
Fish Canyon & $8794-23$ & & $15.03 \pm 0.11$ & \\
Fish Canyon & Sample mean & & & \\
& & 50 & $14.41 \pm 0.13$ & 0.89 \\
Mt Dromedary & $8794-6$ & 67 & $14.01 \pm 0.11$ & 0.88 \\
Mt Dromedary & $8794-7$ & 61 & $13.92 \pm 0.12$ & 0.90 \\
Mt Dromedary & $8794-8$ & & $14.11 \pm 0.07$ & \\
Mt Dromedary & Sample mean & &
\end{tabular}

tainties of fission track ages are reported at the $1 \sigma$ level. Modeled thermal histories of four samples selected from different sub-regions are shown in Figs. 5 and 6.

\subsection{Apatite Fission Track Age versus Mean Track Length}

Figure 4 is a plot of mean track length versus apatite age for samples originating in Marlborough from south of the Wairau Fault. It is useful to examine the data together in this plot before considering the data in transects, because it should reveal broad patterns about the occurrences of annealing zones and the timing of significant cooling events (e.g., Green 1986).

A general boomerang trend is shown in the data, although there are complexities in the pattem for samples with 90 million years or more of age. Samples with very young $(<10 \mathrm{Ma})$ ages have long lengths $(>15 \mu \mathrm{m})$, reflecting very recent and rapid cooling of the host rocks from temperatures exceeding the closure temperature of fission tracks in apatite (taken as 110 ${ }^{\circ} \mathrm{C}$ ). The decrease in mean track length with increasing age from $10 \mathrm{Ma}$ to around $67 \mathrm{Ma}$ is due to a change of the proportion of shorter tracks, annealed during burial (heating) of the basement leading up to a late Cenozoic regional cooling event, versus longer racks formed during the late Cenozoic cooling phases and contributing to the total mean length. This component of the boomerang originates through different samples experiencing increasing levels of partial annealing as the age decreases and length increases. There is a trend in the plot (Fig. 4) for some samples to then increase in mean length with an increase in apatite fission track age from 67 to about $100 \mathrm{Ma}$. This corresponds to decreasing levels of partial annealing for those samples that have more apparent age. The samples with around $100 \mathrm{Ma}$ of ages and long lengths cooled rapidly at around that time, and have remained at low temperatures since then in order to have retained the long mean lengths.

There are eight samples with ages of $90 \mathrm{Ma}$ or more, but lengths of $13 \mu \mathrm{m}$ or less. These samples and their host rocks have probably experienced two or more phases of partial annealing, 
Table 3. Fission track data for Marlborough samples.

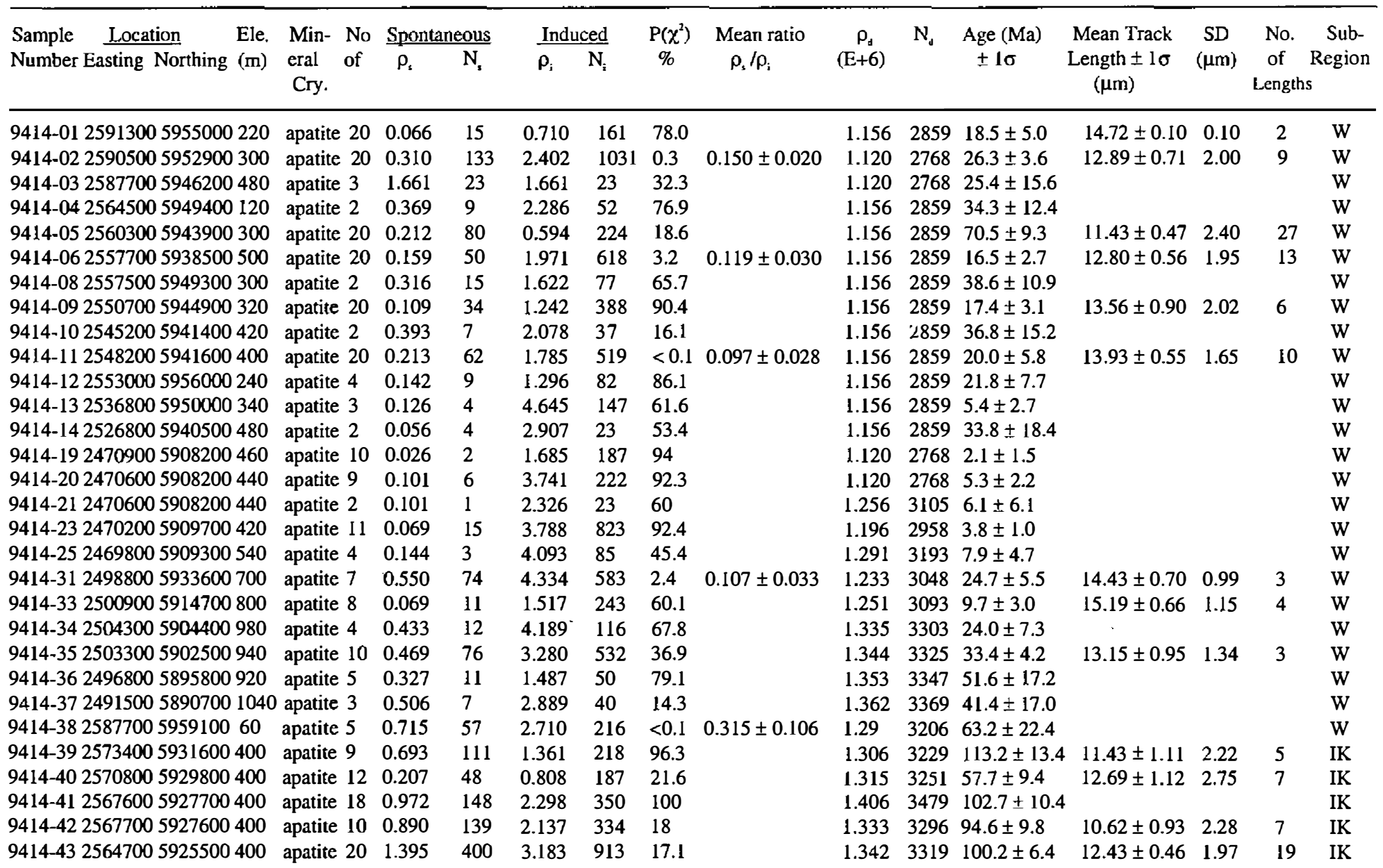


(Table 3. continued)

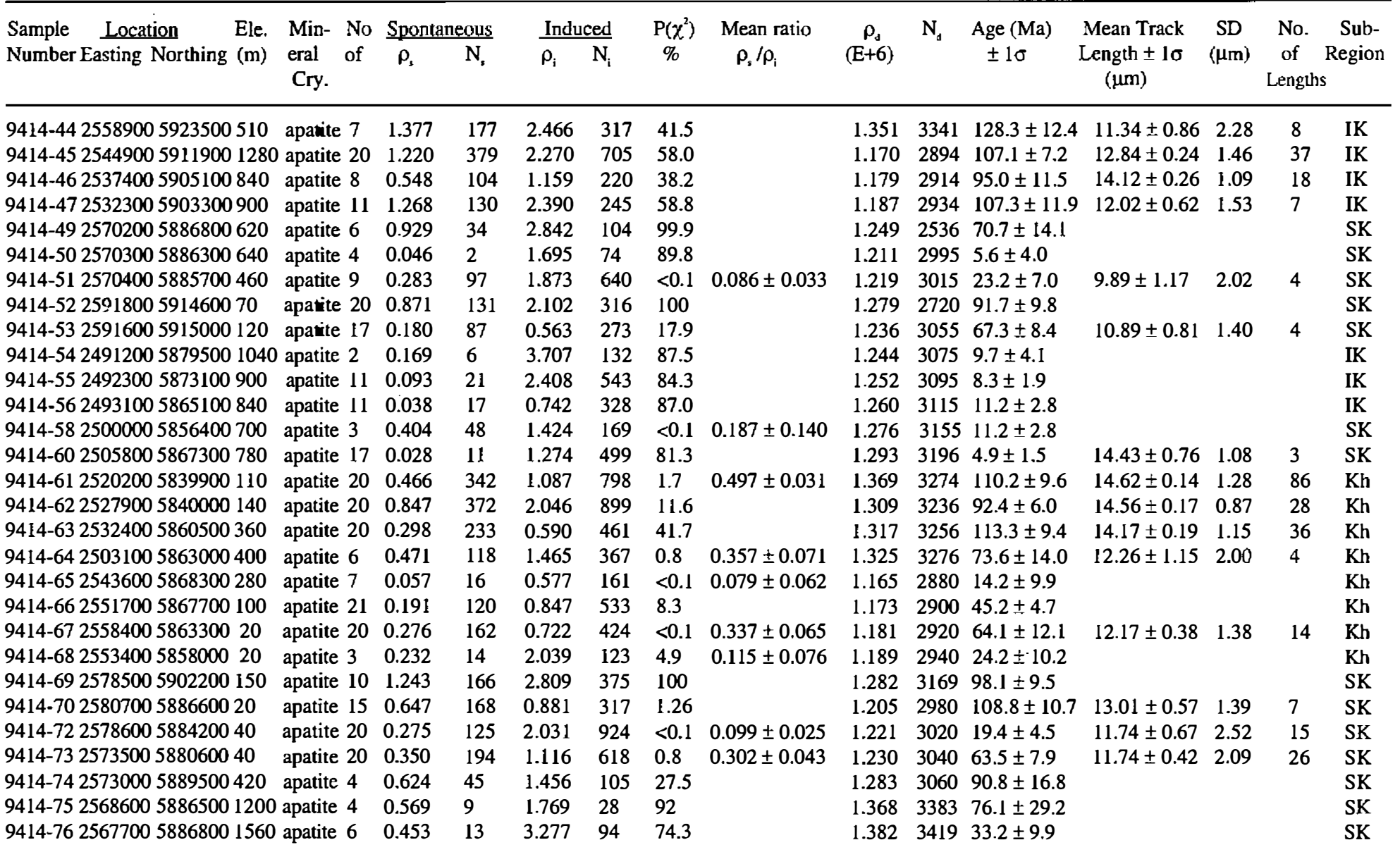


(Table 3. continued)

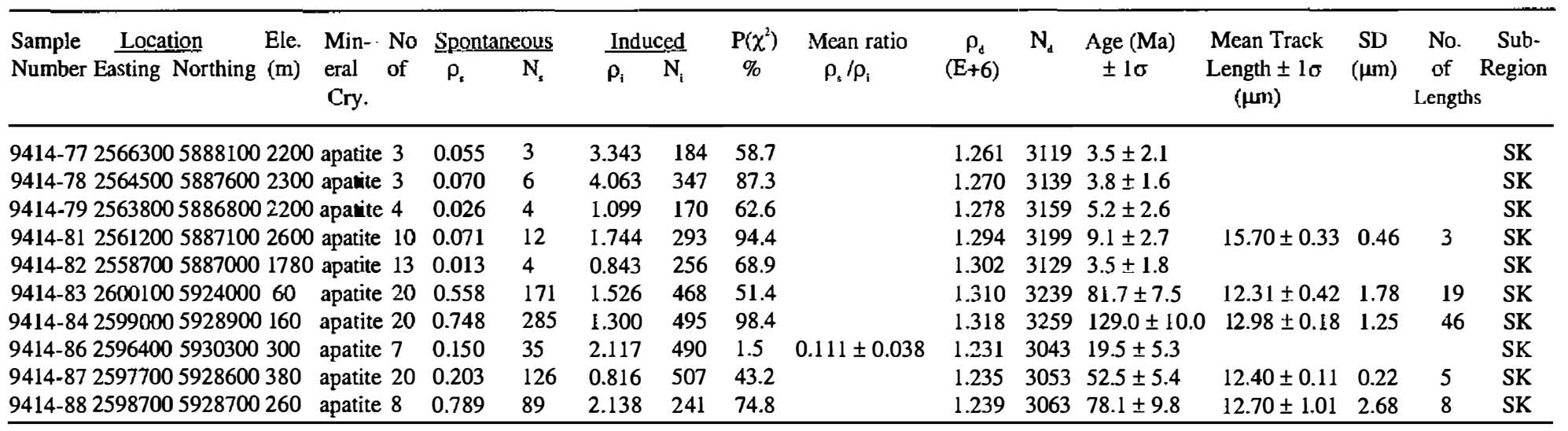

Easting and northing refer to New Zealand Map Series 260 . Track densities $(\rho)$ are $\times 10^{6}$ tracks $\mathrm{cm}^{-2}$. All analyses are by external detector method using 0.5 for the $4 \pi / 2 \pi$ geomenry correction factor. Apatite ages calculated using dosimeter glass SRM 612 and zeta- $612=348.4 \pm 5.8(1 \sigma) ; P\left(\chi^{2}\right)$ is probability of obtaining $\chi^{2}$ value for $v$ degrees of freedom (where $v$ is number of crystals -1 ) [Galbraith 1981]; pooled $\rho / \rho_{\mathrm{i}}$ ration is used to calculate age and uncertainty where $\mathrm{P}\left(\chi^{2}\right)>5 \%$; mean $\rho / \rho_{\text {; }}$ ration is used to calculate age and uncertainty where $\mathrm{P}\left(\chi^{2}\right)<5 \%$ [Green 1981]. Ele.: elevation (m); Cry.: crystals; W: Wairau; IK: Inland Kaikoura; SK: Seaward Kaikoura; Kh: Kahutara. 


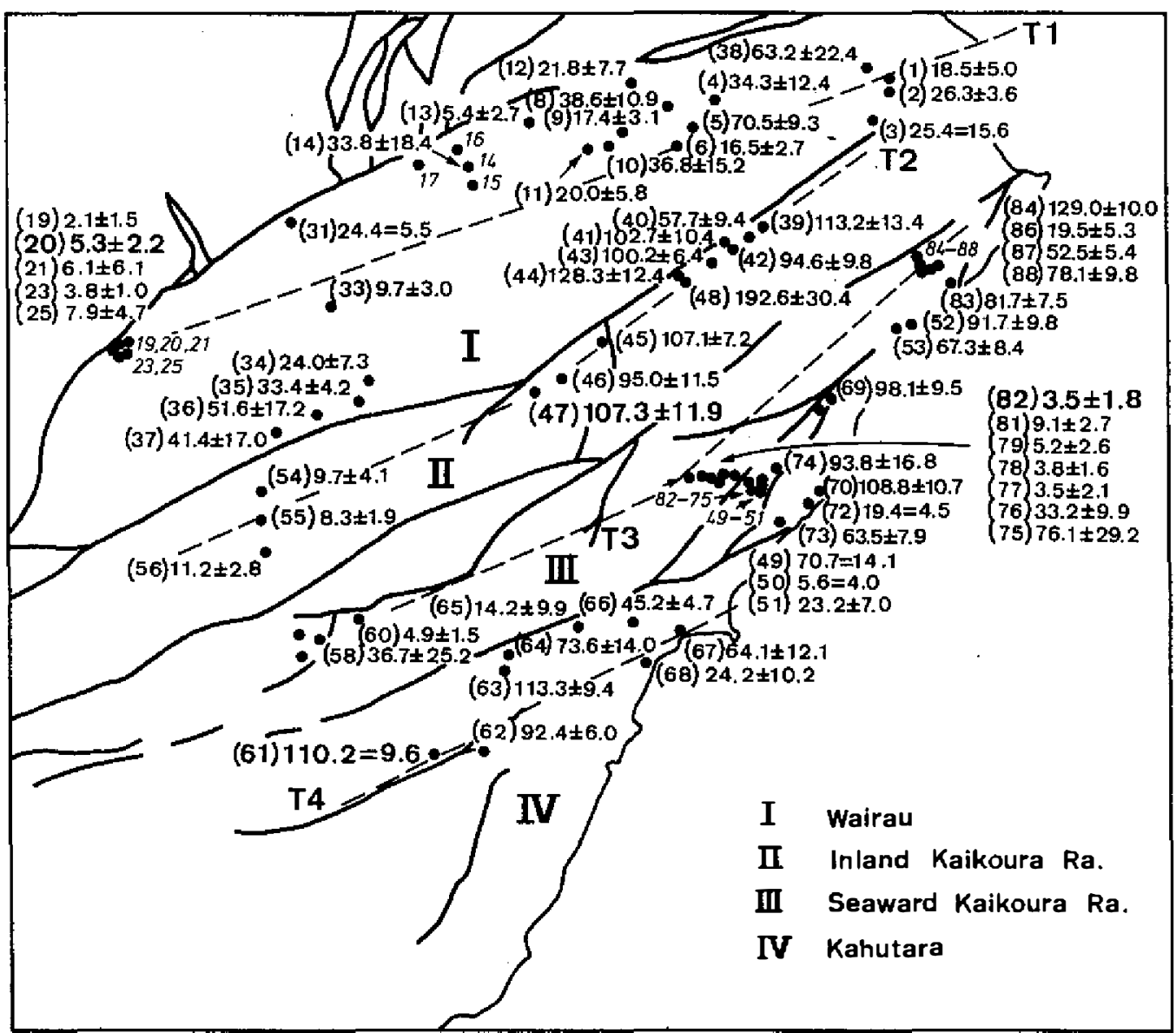

Fig. 2. Distribution of apatite fission track ages (in Ma) of Marlborough. Each sample number, completed by prefix $9414-$, is shown in a parenthesis. The main faults (Fig. 1.) are indicated by solid lines.

one leading up to the mid-Cretaceous, and a second phase during the Cenozoic, with cooling from elevated temperatures possibly around $100 \mathrm{Ma}$ and $10 \mathrm{Ma}$.

\subsection{Apatite Results and Interpretation}

In summary, the plot can be broken up into four parts: (i) Samples-33, -60 and -81 are reset. (ii) Samples on the plot between $9414-1$ and -53 are heavily partially annealed and are inferred to have experienced the lower levels of a partial annealing zone prior to late Cenozoic cooling. (iii) Samples between 9414-5 and -61, and possibly -63, experienced the upper part of a partial annealing zone prior to late Cenozoic cooling. (iv) Samples 9414-39, $-42,-43,-44$, $-45,-47,-70$ and -84 have the most complicated thermal history, and either retained a provenance record, or experienced partial annealing in Marlborough during two intervals. 



Fig. 4. Plot of mean track length versus apatite age for Marlborough samples. Uncertainties are at $1 \sigma$ level. Each sample number is completed by prefix 9414-. 
Based on the pattern of mean fission track lengths versus apatite fission track ages (Fig. 4), the reset samples (9414-1, -31, -46, -61, -62 and -63) reveal two major cooling events, occurring in the Miocene and mid-Cretaceous ( $\sim 100 \mathrm{Ma})$. Samples 9414-33 and -81 reflect the continuing of the cooling event from Pliocene to the present.

\subsection{Modeled Thermal Histories}

Fission track thermal history modeling software, known as "Monte Trax", has been developed by Gallagher (1995) and can be applied to define the thermal histories consistent with observed fission track parameters. This program assumes necessarily that the apatites have a uniform composition. However, it is known from the compositional data reported by Tippett and Kamp (1993) that the apatites in the Triassic sandstones, at least, have variable chlorine contents. No new composition data were obtained in this study, and therefore we assume that the temperature of total annealing in Marlborough apatites is similar to that of Durango apatite $\left(\sim 110^{\circ} \mathrm{C}\right)$. Monte Trax modeling was undertaken on eleven samples obtained from Marlborough (Table 3). These are the samples for which there were reasonable length data. The results of the modeling, which incorporated stratigraphic constraints, where those were available, are shown in Figs. 5 and 6 for Samples 9414-5, -45, -83 and -61.

\subsubsection{Wairau sub-region}

Samples 9414-2, -5 and -11 lie between the Wairau and Awatere Faults and were collected from the NE Wairau block. The basement in this block comprises mainly upper Triassic-Jurassic sandstone (greywacke). Cover strata are of late Miocene and late Quaternary ages. There is no record of Cretaceous to mid-Miocene stratigraphic units, but deposition during this interval cannot be ruled out. The three sample sites may have had similar thermal histories based on their position on the length-age plot (Fig. 4). They will differ however in the maximum temperatures experienced, with the order of increasing paleotemperatures being 9414-11 > 9414-2 > 9414-5, as judged from the positions on the length-age plot (Fig. 4).

The modeling of Sample 9414-5 requires a two stage cooling history (Fig. 5a). The first phase of cooling is required during the mid-Cretaceous, which brought the rocks sampled into the annealing zone. This ended at about $91 \mathrm{Ma}$. There may have been a slight amount of heating from 91-15 Ma, followed by rapid late-early to late Miocene cooling. This phase of cooling achieved through uplift and erosion would have removed the stratigraphic evidence for any sedimentation during the late Cretaceous-Miocene.

\subsubsection{Inland Kaikoura sub-region}

Samples 9414-45 taken from the Inland Kaikoura Range lies between the Awatere and Clarence Faults. The stratigraphic components of the basement in the Inland Kaikoura block are similar to those of the Wairau block. The depositional ages of cover strata range from Cretaceous to Quaternary. The cover strata occur in the central to north-east parts of the Inland Kaikoura Range. The late Miocene and Quaternary rocks are limited to the north- 
(a)
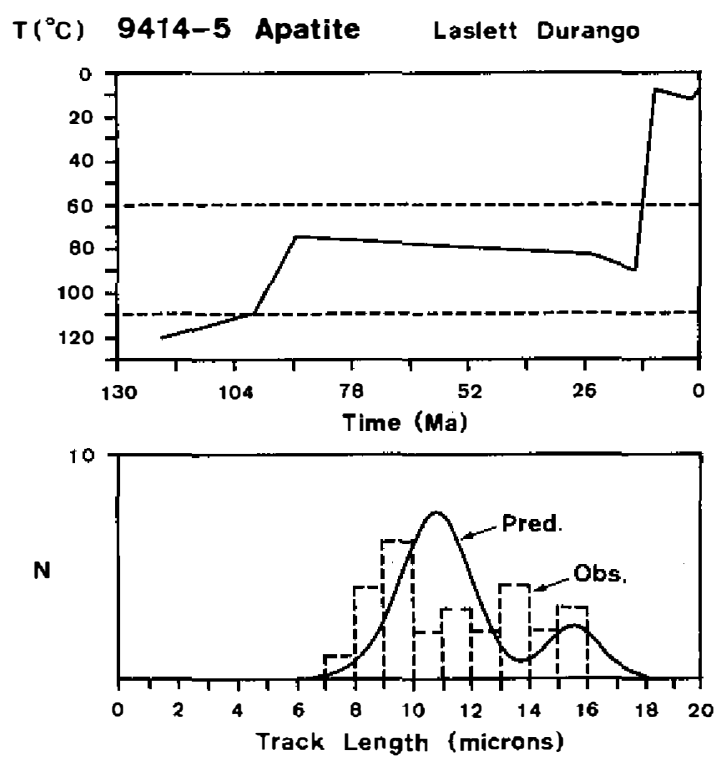

(b)
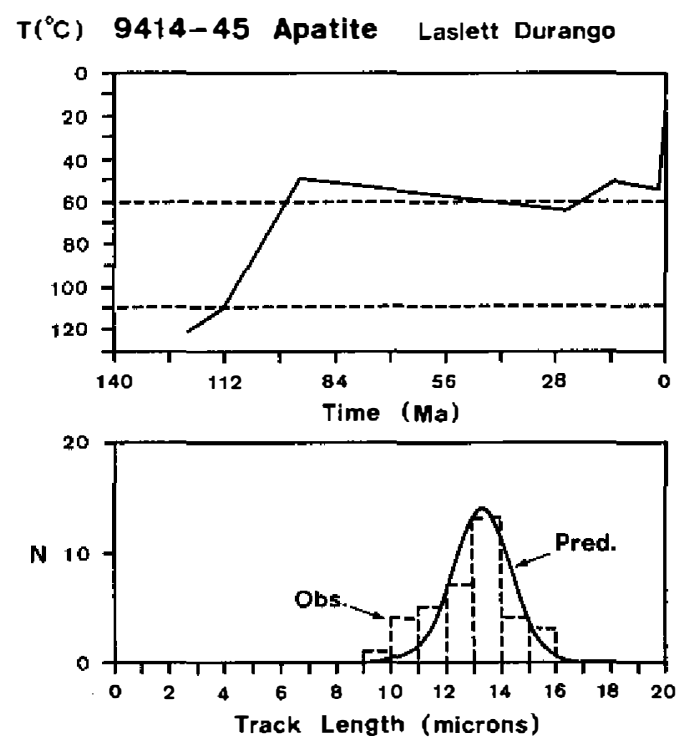

Fig. 5. (a) Modeled thermal history of Sample 9414-5. (Top) The region between two dashed lines presents the apatite partial annealing zone. The molded history is shown by solid lines. (Bottom) The modeled result is indicated by the comparison of the distributions of observed (Obs.) and predicted (Pred.) fission-track lengths. (b) Modeled thermal history of Sample 9414-45. 
(a)
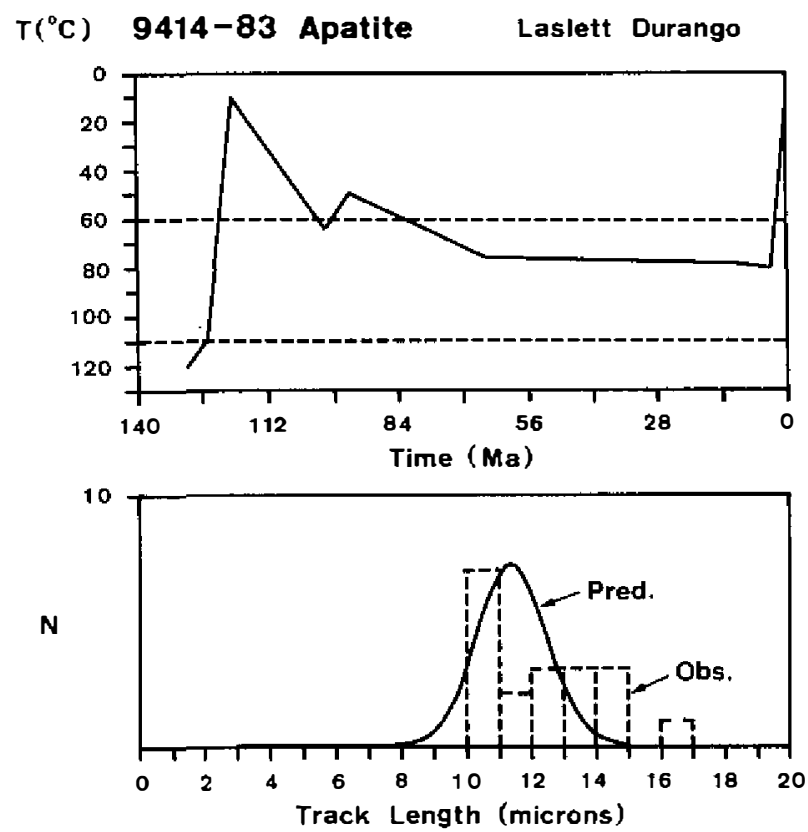

(b)
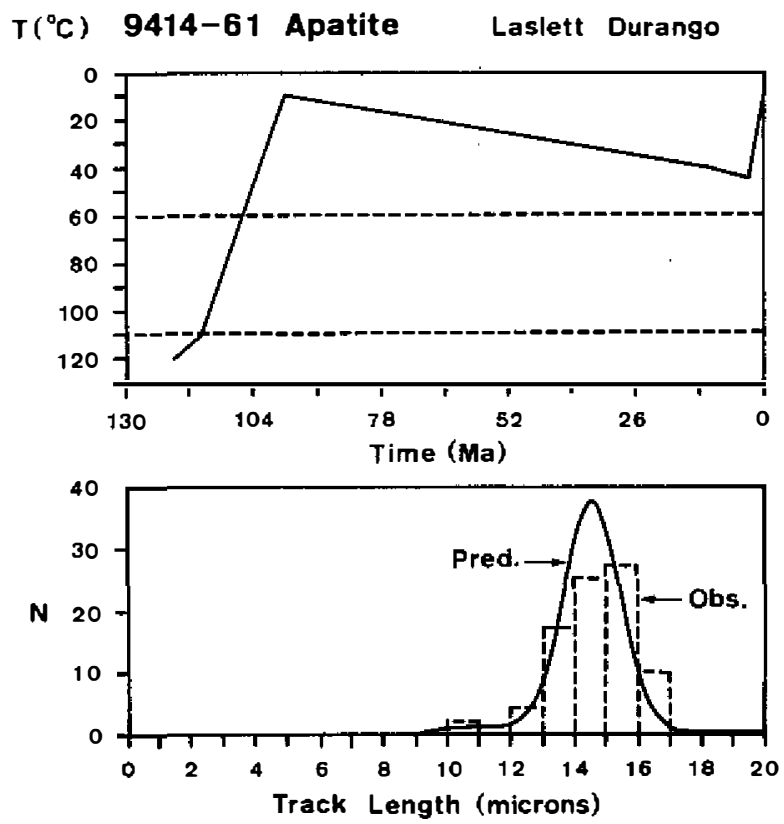

Fig. 6. Modeled thermal histories of two samples (a) 9414-83 and (b) 9414-61. See Fig. 5 for the illustrations. 
easternmost end of the Awatere Valley. The host rocks of Sample 9414-45 are of mid-Cretaceous age. The modeled thermal history of this sample (Fig. 5b) indicates that apatites cooled rapidly in the source area during the mid-Cretaceous, were deposited at about $100 \mathrm{Ma}$ and reached maximum temperature $\left(65^{\circ} \mathrm{C}\right)$ prior to Neogene cooling.

\subsubsection{Seaward Kaikoura sub-region}

Samples 9414-83 was collected from the Seaward Kaikoura block (Fig. 6.a). This sample was difficult to model, that is, to get all predicted and observed parameters to match. However, the modeling was sufficient to estimate the maximum temperatures prior to Neogene erosion. Sample 9414-83 is a Motuan (Albian) sandstone. Modeling shows that this sample has probably been heated to a maximum temperature of about $82^{\circ} \mathrm{C}$ (Fig. 6a). The apatites seem to have cooled during the early Cretaceous, were deposited in the basin with about 20 m.y. of inherited age, experienced some cooling during the early-late Cretaceous, and heating through burial during the late Cretaceous-Miocene.

\subsubsection{Kahutara sub-region}

Samples 9414-61 comes from the site south of the Hope Fault (Fig. 1), and has Jurassic depositional age. In Fig. 4 this sample has long mean lengths and comparatively old age. The modeling result is moderately successful (Fig. 6b). The sample shows a strong mid-Cretaceous cooling phase that brought the host rocks up to near the surface. This was followed by late Cretaceous-Cenozoic heating through burial and accommodation of cover strata, followed by late Pliocene-Pleistocene uplift and erosion of that cover succession. Maximum temperature achieved prior to the latest phase of uplift and erosion is $\sim 45^{\circ} \mathrm{C}$.

\subsubsection{Interpretation of modeled thermal history}

In this section samples with good length data have been selected for modeling of the thermal histories. The samples were selected to sample all parts of the length-age plot (Fig. 4). What has emerged is that all samples modeled retain same evidence for a mid-Cretaceous cooling event, even where there has been major late Cenozoic cooling. Samples with very young ages and long lengths have not been modeled because of the inadequacy of the length data, but these would not see back to the mid-Cretaceous event because they were totally reset by the recent uplift and denudation. The results of modeled Jurassic rocks, far western parts of Marlborough, tend to show the cooling event as having occurred during the Motuan (Albian), whereas the annealed Motuan rocks show a slightly later phase of uplift (94-90 Ma) and retain a provenance signal that "sees" back to the early Cretaceous.

In all cases the modeling is consistent with late Cretaceous-Oligocene burial/heating, but this can be minor in the western parts of Marlborough where these rocks are not present. Meanwhile, the modeled results show that the timing of the main Neogene uplift/erosion event varies, being earlier (mid to late Miocene) in the north (Wairau block) and later (late PliocenePleistocene) in the southeast (Seaward Kaikoura Range). The samples in Fig. 4 that have 
older ages (>90 Ma) but intermediate lengths (11-13 $\mu \mathrm{m}$ ) appear to be from host rocks that were uplifted during the mid-Cretaceous into lower parts of a partial annealing zone, and experienced some subsequent late Cretaceous-Cenozoic burial. The consequence of spending considerable time in the zone of partial annealing, and only recent uplift, has been retention of age relative to length.

\section{CONCLUSIONS}

The very young ages $(<10 \mathrm{Ma})$ of apatite in the vicinity of the Alpine Fault bend and Seaward Kaikoura Range, can be correlated with the recent rapid uplift/erosion in these areas. Most of the apatite ages are younger than depositional ages, revealing that the host rocks in Marlborough have experienced exposure to temperatures in the zone of partial annealing for apatite. In addition, apatite ages obtained along the Wairau Fault are always younger than those of other areas. Apatite fission track ages and mean lengths indicate that there are two major cooling events, one occurring from the early Miocene ( 20 Ma) and the other in the mid-Cretaceous $(-100 \mathrm{Ma})$. Modeled thermal histories of selected samples with good length data are consistent with the stratigraphic record and reflect that in the Wairau block the timing of the main Neogene uplift/erosion event is earlier (mid to late Miocene) than to the southeast in the Seaward Kaikoura Range (late Pliocene-Pleistocene).

Acknowledgements I would like to thank Professor Peter Kamp for his guidance and experimental support. The experimental work was completed at the Fission Track Lab of the Earth Sciences Department, University of Waikato, New Zealand. This manuscript had been written up when the author was a postdoctoral fellow at the Institute of Earth Sciences, Academia Sinica, Taipei, Taiwan in 2000. The support of Research Fellows, H.C. Chiu and T.F. Yui, is highly appreciated. Finally, I am grateful to two anonymous reviewers for their suggestions and comments.

\section{REFERENCES}

Baker, J., and D. Seward, 1996: Timing of Cretaceous extension and Miocene compression in northeast South Island, New Zealand: Constraints from $\mathrm{Rb}-\mathrm{Sr}$ and fission-track dating of an igneous pluton. Tectonics, 15, 5, 976-983.

Bradshaw, J. D., C. J. Adams, and P. B. Andrews, 1981: Carboniferous to Cretaceous in the Pacific margin of Gondwana: the Rangitata phase of New Zealand, 217-212, In Cresswell, M. M., Vella, P. (Eds), Gondwana Five.

Browne, G. H., 1995: Sedimentation patterns during the Neogene in Marlborough, New Zealand. J. Roy. Soc. N. Z., 25, 4, 459-483.

Carter, R. M., and L. Carter, 1982: The Motunau Fault and other structures at the southern edge of the Australia-Pacific plate boundary, offshore Marlborough, New Zealand. Tectonophysics, 88, 133-159.

Carter, R. M., and R. J. Norris, 1976: Cainozoic history of Southem New Zealand: An accord between geological observations and plate tectonic predictions. Earth and Planet. Sci. 
Lett., 31, 85-94.

Christoffel, D. A., 1971: Motion of the New Zealand Alpine Fault deduced from the sea-floor spreading. Bull. R. Soc. N. Z., 9, 25-30.

Crowley, K. D., M. Cameron, and R. L. Schaeffer, 1991: Experimental studies of annealing of etched fission tracks in fluorapatite. Geochimi. et Cosmochi. Acta, 55, 1449-1465.

Dodson, M. H., 1973: Closure temperature in cooling geochronological and petrological systems. Contrib. Mineral. Petrol., 40, 259-274.

Duddy, I. R., P. F. Green, and G. M. Laslett, 1988: Thermal annealing of fission tracks in apatite 3. Variable temperature behaviour. Chem. Geol. (Isot. Geosci. Sect.), 73, 2538.

Galbraith, R. F., 1981: On statistical models for fission track counts. Mathematical Geology, 13, 471-478.

Gailagher, K., 1995: Monte Track - A fission track thermal history modelling program for the Macintosh. Dept. of Earth Sciences, The Open University, Milton Keynes and Dept. of Geological Sciences, UCL, London.

Gleadow, A. J. W., 1981: Fission track dating methods: What are the real alternatives? Nucl. Tracks, 5, 3-14.

Gleadow, A. J. W., and I. R. Duddy, 1981: A natural long-term track annealing experiment for apatite. Nucl. Tracks, 5, 169-174.

Green, P. F., 1985: Comparison of zeta calibration baselines for fission rack dating of apatite, zircon and sphene. Chem. Geol., 58, 1-22.

Green, P. F., 1986: On the thermo-tectonic evolution of Northern England: Evidence from fission track analysis. Geol. Mag., 123, 493-506.

Green, P. F., I. R. Duddy, G. M., Laslett, K. A. Hegarty, A. J. W. Gleadow, and J. F. Lovering, 1989a: Thermal annealing of fission tracks in apatites 4. Quantitative modelling techniques and extension to geological time scales. Chem. Geol. (Isot. Geosci. Sect.), 79, 155-182.

Green, P. F., I. R. Duddy, A. J. W. Gleadow, and J. F. Lovering, 1989b: Apatite fission track analysis as a paleotemperature indicator for hydrocarbon exploration, in Thermal history of sedimentary basins. In: N. D. Naeser, and T. H. McCulloch (Eds.), SpringerVerlag, New York.

Hodges, K. V., 1991: Pressure-Temperature-Time Paths. Annual Reviews of Earth and Planet. Sci. Lett., 19, 207-236.

Hurford, A. J., 1986: Cooling and uplift patterns in the Lepontine Alps South Central Switzerland and age of vertical movement on the Insubric fault line. Contrib. Mineral. Petrol., 92, 413-427.

Hurford, A. J., 1990: International union of geological sciences subcommission on geochronology: Recommedation for the standardization of fission track dating calibration and data reporting. Nucl. Tracks, 17, 233-236.

Hurford, A. J., and P. F. Green, 1982: A users' guide to fission track dating calibration. Earth and Planet. Sci. Lett., 59, 343-354.

Hurford, A, J., and R. T. Watkins, 1987: Fission track age of the tuffs of the Buluk Member, Bakate Formation, northern Kenya: A suitable fission track age standard. Chem. Geol., 
66, 209-216.

Kamp, P. J. J., P. F. Green, and S. H. White, 1989: Fission track analysis reveals character of collisional tectonics in New Zealand. Tectonics, 8, 169-195.

Kamp, P. J. J., and J. M. Tippett, 1993: Dynamics of Pacific Crust in South Island (New Zealand) Zone of Oblique Continent-Continent Convergence. J. Geophys. Res., 98, B9, 16105-16118.

Kao, M.-H., 1998: Tectonic Evolution of the Marlborough Region, South Island, New Zealand, (Unpublished) Ph.D., University of Waikato, New Zealand.

Lamb, S. H., 1988. Tectonic rotations about vertical axes during the last $4 \mathrm{Ma}$ in part of the New Zealand plate-boundary zone. J. Struct. Geol., 10, 875-893.

Laslett, G. M., W. S. Kendall, A. J. W. Gleadow, and I. R. Duddy, 1982: Bias in the measurement of fission tracks length distributions. Nucl. Tracks, 6, 79-85.

Laslett, G. M., P. F. Green, I. R. Duddy, and A. J. W. Gleadow, 1987. Thermal annealing of fission tracks in apatite, 2. A quantitative analysis. Chem. Geol. (Isot. Geosci Sect.), 65, $1-13$.

Lensen, G. J., 1962: Sheet 16, Kaikoura (1st Edn). Geological Map of New Zealand 1:250, 000, Department of Scientific and Industrial Research, Wellington, New Zealand.

Mumme, T. C., S. H. Lamb, and R. I. Walcott, 1989: The Raukumara palaeomagnetic domain : constraints on the tectonic rotation of the east, North Island, New Zealand, from palaeomagnetic data. N.Z. J. of Geol. and Geophy., 32, 317-326.

Naeser, C. W., 1979: Thermal history of sedimentary basins in fission track dating of subsurface rocks. Spec. Publ. Soc. Econ. Paleont. Miner., 26, 109-112.

Roberts, A. P., 1992: Paleomagnetic constraints on the tectonic rotation of the Southern Hikurangi Margin, New Zealand. N.Z. J. of Geol. and Geophys., 35, 311-323.

Rohrman, M., P. van der Beek, and P. Andriessen, 1994: Syn-rift thermal structure ans postfift evolution of the Oslo rift (southeast Norway): new constraints from fission track thermochronology. Earth and Planet. Sci. Lett., 127, 39-54.

Stock, J., and P. Molnar, 1982: Uncertainties in the relative positions of the Ausuralia, Antarctica, Lord Howe, and Pacific plates since the Late Cretaceous, J. of Geophys. Res., 87B, 4697-4714.

Suggate, R. P., 1978: In Suggate, R. P., Stevens, G. R., Te Punga, M. T. (Eds). The Kaikoura Orogeny, Chapter 10, The geology of New Zealand.

Tippett, J. M., and P. J. J. Kamp, 1993: Fission track analysis of the Late Cenozoic vertical kinematics of continental Pacific crust, South Island, New Zealand. J. Geophys. Res., 98, 16119-16148.

Vickery, S., and S. Lamb, 1995: Large tectonic rotations since the Early Miocene in a convergent plate-boundary zone, South Island, New Zealand. Earth and Planet. Sci. Lett., 136, 43-59.

Walcott, R.I., 1978: Present tectonics and Late Cenozoic evolution of New Zealand. Geophys. J. Roy. Astr. Soc., 52, 137-164.

Wellman, H. W., 1971: Reference lines, fault classification, transform systems, and oceanfloor spreading. Tectonophysics, 12, 199-209. 